A.V. Babkin, Yu.V. Vertakova, V.A. Plotnikov

\title{
ASSESSING THE ECONOMIC EFFICIENCY OF CLUSTER FUNCTIONING: A QUANTITATIVE APPROACH
}

\author{
А.В. Бабкин, Ю.В. Вертакова, В.А. Плотников \\ ОЦЕНКА ЭКОНОМИЧЕСКОЙ ЭФФЕКТИВНОСТИ \\ ФУНКЦИОНИРОВАНИЯ КЛАСТЕРОВ: КОЛИЧЕСТВЕННЫЙ ПОДХОД
}

The cluster approach, i.e., forming basic innovative and industrial clusters has gained wide circulation in modern Russian conditions for the development of the economy. These actions are considered by federal and regional authorities as effective measures for implementing the economic policy stimulating regional development. The analysis we carried out showed that the quantitative approach for assessing the efficiency of cluster creation and performance is still insufficiently used. In this paper we establish and quantitatively estimate the influence cluster have on the regional economy using regression analysis with an example of a number of Russian regional clusters. It is offered to expand the practice of creation and the state support of clusters taking into account the revealed quantitative dependences estimating their efficiency. We have advanced the hypothesis that clustering has a positive influence on regional economy, and confirmed this influence by means of quantitative methods using representative datasets. Our study of course had a selective character as it is not possible to carry out calculations for all existing clusters and cluster initiatives of Russia and discuss the results within a single article. At the same time, following the analysis we performed, we concluded that it is effective to initiate cluster creation in Russian regions. It is shown that cluster activity is capable to have of having a positive impact on GRP growth and the budgetary income in the region. Along with that, we note the dissimilarities in the multiplying influence of clusters on the regional development, its dependence on territorial and branch specifics that will be the direction for a further in-depth study.

CLUSTER POLICY; CLUSTER; EFFICIENCY ASSESSMENT; REGIONAL ECONOMY; REGIONAL DEVELOPMENT.

В современных российских условиях широкое распространение получил кластерный подход, заключающийся в формировании базовых инновационных и инновационно-промышленных кластеров. Эти действия рассматриваются федеральными и региональными органами государственного управления как эффективная мера реализации экономической политики, стимулирующая региональное развитие. Проведенный анализ показал, что при этом пока еще недостаточно используется количественный подход для оценки эффективности создания и функционирования кластеров. На примере ряда российских региональных кластеров с использованием метода регрессионного анализа выявлено и количественно оценено их влияние на региональную экономику. Предлагается расширить практику создания и государственной поддержки функционирования кластеров с учетом выявленных количественных зависимостей, оценивающих их эффективность. Выдвинутая гипотеза о наличии положительного влияния процессов кластеризации на экономику регионов в ходе исследований нашла количественное подтверждение. Причем, это влияние доказано при помощи количественных методов с использованием репрезентативных рядов данных. Исследование, безусловно, носит выборочный характер, так как провести расчеты по всем заявленным кластерам России и кластерным инициативам и обсудить их результаты в рамках одной статьи не представляется возможным. Сделан вывод об эффективности инициирования создания кластеров в регионах России. Показано, что их деятельность способна оказывать положительное влияние на рост ВРП и бюджетных доходов в регионе. Одновременно с этим отмечены неодинаковость мультиплицирующего влияния кластеров на региональное развитие, его зависимость от территориальных и отраслевых особенностей как направления дальнейшего углубленного исследования.

КЛАСТЕРНАЯ ПОЛИТИКА; КЛАСТЕР; ОЦЕНКА ЭФФЕКТИВНОСТИ; РЕГИОНАЛЬНАЯ ЭКОНОМИКА; РЕГИОНАЛЬНОЕ РАЗВИТИЕ.

Cluster initiatives are widely adopted in modern Russia. According to the Russian cluster observatory (http://map.cluster.hse.ru/list - the
Map of Clusters of Russia project), now 99 organized clusters can be identified in the country. Other sources give slightly different 
estimates on the quantity of clusters in the Russian Federation, but it isn't concrete numbers, and in qualitative result. Clusters became a noticeable phenomenon, especially at the regional level of the national economy. Because of this, many publications are dedicated to studying them $[1,3,4,7,8,11-15$, etc. $]$ (we should note that the authors of this article also made a certain contribution to studying these issues $[2,5,6,9,10$, etc. $])$.

While we do not intend to analyze cluster and the publications dedicated to them in detail, we should point out on circumstance that is important in our opinion: cluster organization of economic associations is confirmed to be rather effective both in theory and in practice. This article is dedicated to critical consideration of this statement. We will use methods of quantitative analysis for assessing the efficiency of cluster organization of economic activity.

We used the above-mentioned Map of clusters of Russia as basic data for carrying out calculations. Since it contains numerous objects and our computing and temporal resources were limited, we selected four clusters from the entire set (Tab. 1). We selected the clusters for study based on the premise that if some clusters existed in the same branch, preference was given to the cluster with a higher level of organizational development or functioning during a longer period. We also paid attention to the existence of necessary statistical information on clusters. Besides, when forming our selection, we strived to make it cover various non-related branches to obtain more objective results.

Table 1

Selection of clusters for quantitative analysis

\begin{tabular}{|c|c|c|c|c|}
\hline Cluster, region & Branch & Participants of cluster & $\begin{array}{c}\text { Level of } \\
\text { organizational } \\
\text { development }\end{array}$ & $\begin{array}{c}\text { Year of } \\
\text { establishment }\end{array}$ \\
\hline $\begin{array}{l}\text { Textile cluster of the } \\
\text { Ryazan Oblast }\end{array}$ & $\begin{array}{l}\text { Production of } \\
\text { textile products, } \\
\text { clothes, footwear, } \\
\text { leather products }\end{array}$ & $\begin{array}{l}\text { Valentin Yudashkin, Kadomsky Veniz, } \\
\text { Korablinsky Textile Factory, Corporation of } \\
\text { Fevelopment of the Ryazan Oblast, } \\
\text { National Investment and Finance } \\
\text { Corporation, Skopinsky Clothing Factory, } \\
\text { Truzhenitsa, Municipal Administration of } \\
\text { the Korablinsky municipal area, the } \\
\text { Ministry of economic development and } \\
\text { trade of the Ryazan Oblast, Branch of the } \\
\text { Ivanovo State Textile Academy in Ryazan, } \\
\text { Agrotechnological Technical School (of } \\
\text { Korablino) }\end{array}$ & Initial & 2014 \\
\hline $\begin{array}{l}\text { Power cluster of } \\
\text { Tula region }\end{array}$ & $\begin{array}{l}\text { Electricity } \\
\text { generation and } \\
\text { electric } \\
\text { equipment }\end{array}$ & $\begin{array}{l}\text { Quadra Power Generation, Transelektro, } \\
\text { Tula City Electric Networks, Aleksinsky } \\
\text { combined heat and power plant, } \\
\text { Efremovskaya TPP (production division of } \\
\text { Quadra Power Generation), Novomoskovsk } \\
\text { state district power station (production } \\
\text { division of Quadra Power Generation), } \\
\text { Pervomayskaya combined heat and power } \\
\text { plant (production division of Quadra Power } \\
\text { Generation), Tulenergo Branch IDGC of } \\
\text { Centre and Volga region, D.G. Zhimerin } \\
\text { Cherepetskaya GRES Branch of Inter RAO } \\
\text { Elektrogeneration joint-stock company, } \\
\text { Shchyokinsky state district power station } \\
\text { (production division of the Quadra Tula } \\
\text { branch) }\end{array}$ & Initial & 2012 \\
\hline
\end{tabular}


The end of Tab. 1

\begin{tabular}{|c|c|c|c|c|}
\hline Cluster, region & Branch & Participants of cluster & $\begin{array}{l}\text { Level of } \\
\text { organizational } \\
\text { development }\end{array}$ & $\begin{array}{c}\text { Year of } \\
\text { establishment }\end{array}$ \\
\hline $\begin{array}{l}\text { Innovative territorial } \\
\text { timber industry cluster } \\
\text { Arkhangelsk region } \\
\text { Pomorinnovales }\end{array}$ & $\begin{array}{l}\text { Forestry and } \\
\text { woodworking; } \\
\text { pulp and paper } \\
\text { production }\end{array}$ & $\begin{array}{l}\text { Alliance Teplo Energo, Arkhangelsk Repair } \\
\text { and Operational Base of Fleet, Arkhangelsk } \\
\text { Sea Commercial Port, Arkhangelsk Plywood } \\
\text { Plant, Roslesinforg, Arkhangelsk Pulp and } \\
\text { Paper Mill, Arkhbioenergo, Arkhbum, } \\
\text { Arkhgiprobum, Belomorskiy Les, Biolaboratory } \\
\text { Farm, Timber Mill 25, Liszt, Niva, } \\
\text { Novodvinsk Industrial Technical School, } \\
\text { Nord-Wood, Nordtekhsad, Titan Group, } \\
\text { Plesetsk Logging Enterprise, Pomor forest } \\
\text { science and technology park, Priroda, } \\
\text { Interstroy Production Company, Northern } \\
\text { Shipping Company, Northern Research } \\
\text { institute of forestry, Tekhnoservice, Trast, } \\
\text { Office of the Federal Penitentiary Service of } \\
\text { the Arkhangelsk Oblast, Gudkov, Korelsky } \\
\text { and Smolyarzh Law Firm }\end{array}$ & Average & 2014 \\
\hline $\begin{array}{l}\text { Dairy cluster of the } \\
\text { Vologda region }\end{array}$ & $\begin{array}{l}\text { Agriculture and } \\
\text { fishery }\end{array}$ & $\begin{array}{l}\text { Union Stud Farm, Abiogroup, Agrokon- } \\
\text { Vologda, Agrokorm, Agromolservice, Chushevitsa } \\
\text { Agro-industrial complex, Agrotekhnika- } \\
\text { Vologda, Anokhinsky SPK, Babushkinskoe } \\
\text { Moloko, Kolkhoz Verny SPK, } \\
\text { Vologdaburvodservice, Grinbiotekh-Agro, } \\
\text { Zarya, Zoovetfarm-Region, C/A Kalinin } \\
\text { Kolkhoz, KFH Krendelev R.L., Totemsky Butter } \\
\text { Factory, Mechanikov A.A. Farm, Mekhanikov } \\
\text { M.V. Farm, Myzin A.V. Farm, Myaksinsky } \\
\text { Kolkhoz, Nizhne-Kuloye Kolkhoz SPK, } \\
\text { Otkrity Mir Kormov, Mayskiy Stud Farm } \\
\text { SPK, Cherepovetskoye Plempredpriyatiye, } \\
\text { Vologodskoye Plemproizvoditel, Pokrovskoye, } \\
\text { Prisukhonskoye SHPK, Protemol, Rus SPK, } \\
\text { Kolkhoz Sever SPK, Simakina E.V. } \\
\text { Farm., Spirina G.S. Farm, Tarnogsky Butter } \\
\text { Farm, Vozhrozhdenie UK, Progress UK, } \\
\text { Ferapontovo SPK, Sheksna, Sheksninskaya } \\
\text { Zarya, Elitniye Semena }\end{array}$ & Initial & 2015 \\
\hline
\end{tabular}

S o u r c e: data of the Russian cluster observatory (http://map.cluster.hse.ru/list).

We considered the following resultant indicators: level of economic development of the region, which is estimated quantitatively through GRP per capita (thousands of rubles), as well as the income of the budget (the average per capita indicator measured in thousands of rubles per person per year was also considered). We estimated how these indicators changed under the influence of cluster initiatives introduced by the regions under consideration. Since the assessed clusters operate in various branches of specialization, we used similar indicators for quantitative assessment. These included the volume of investment and output, but considered not for the region as a whole but only for branches of cluster specialization (Figure). Thus, the average per capita estimates measured in thousands of rubles were also used. 


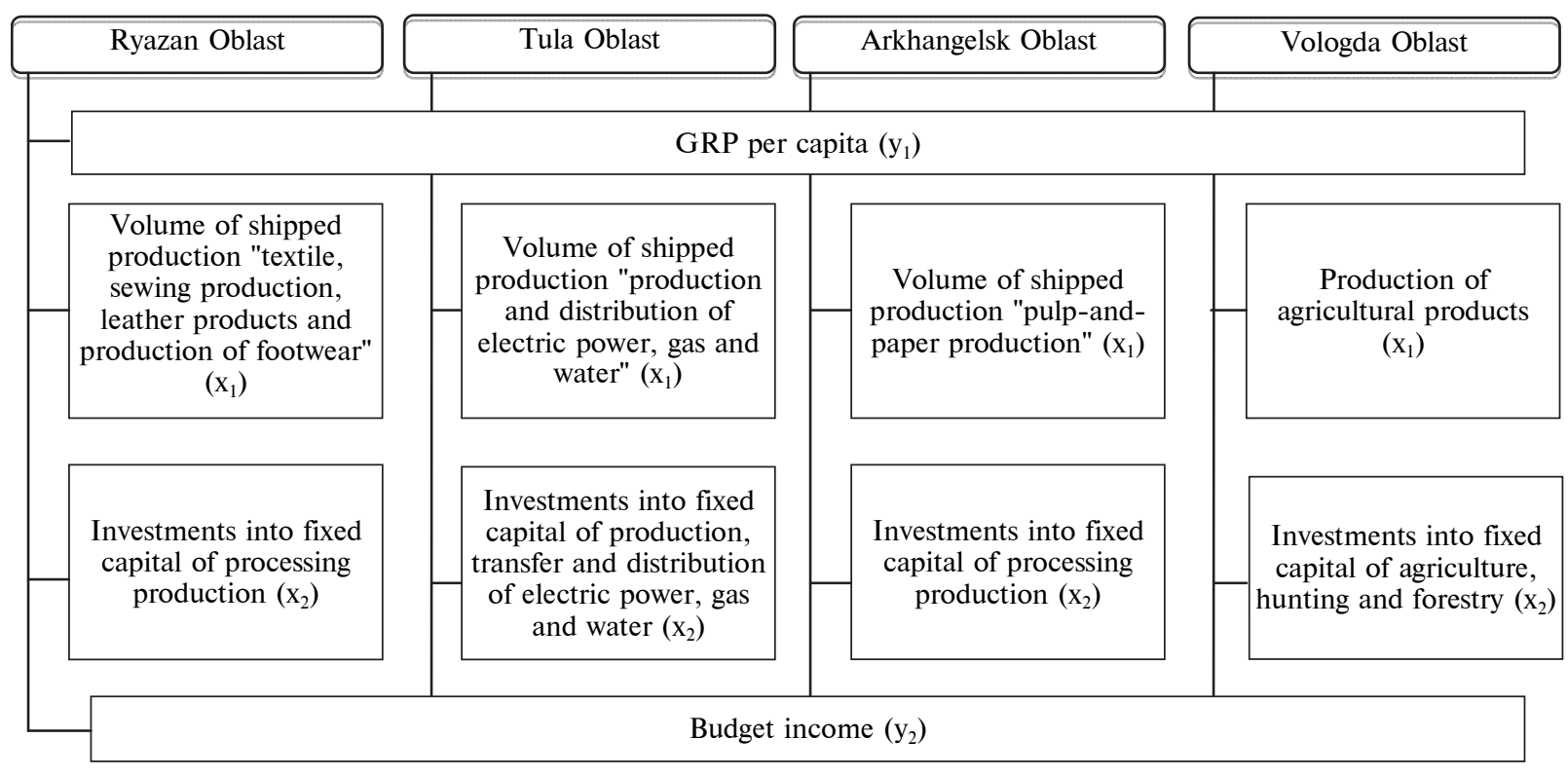

Resultant and factorial indicators for the analysis of clusters

Information from statistical collections of Rosstat was used as basic data for calculations. The period from 2004 to 2014 was covered. The regression analysis method was used which allows to estimate the extent of mutual influence of the considered indicators with a sufficiently high degree of accuracy. Linear one- and two-factorial equations of regression were constructed, given in Tab. 2 (only the dependences which have a high degree of accuracy, estimated by the determination coefficient $\mathrm{R}^{2}$, are presented in the table).

Table 2

Regression dependences of indicators of analyzed clusters and regions

\begin{tabular}{|c|c|c|c|}
\hline Oblast & Indicators & Regression equation & $\mathrm{R}^{2}$ \\
\hline \multirow[t]{2}{*}{ Ryazan Oblast } & GRP per capita $\left(\mathrm{y}_{1}\right)$ & $\begin{array}{l}\mathrm{y}_{1}=21.488+13.45209 \mathrm{x}_{2} \\
\mathrm{y}_{1}=17.385+5.776 \mathrm{x}_{1}+13.01 \mathrm{x}_{2}\end{array}$ & $\begin{array}{l}0.86 \\
0.88 \\
\end{array}$ \\
\hline & Budget income $\left(\mathrm{y}_{2}\right)$ & $\begin{array}{l}\mathrm{y}_{2}=6.03933+2.03368 \mathrm{x}_{2} \\
\mathrm{y}_{2}=5.829+0.296 \mathrm{x}_{1}+2.011 \mathrm{x}_{2}\end{array}$ & $\begin{array}{l}0.82 \\
0.82\end{array}$ \\
\hline \multirow[t]{2}{*}{ Tula Oblast } & GRP per capita $\left(\mathrm{y}_{1}\right)$ & $\begin{array}{l}\mathrm{y}_{1}=11.89458+11.858 \mathrm{x}_{1} \\
\mathrm{y}_{1}=85.95291+13.198 \mathrm{x} 2 \\
\mathrm{y}_{1}=15.441+8.267 \mathrm{x}_{1}+7.116 \mathrm{x}_{2}\end{array}$ & $\begin{array}{l}0.79 \\
0.67 \\
0.91\end{array}$ \\
\hline & Budget income $\left(\mathrm{y}_{2}\right)$ & $\begin{array}{l}\mathrm{y}_{2}=1.885+2.206 \mathrm{x}_{1} \\
\mathrm{y}_{2}=16.144+2.376 \mathrm{x}_{2} \\
\mathrm{y}_{2}=2.482+1.602 \mathrm{x}_{1}+1.197 \mathrm{x}_{2}\end{array}$ & $\begin{array}{l}0.76 \\
0.63 \\
0.89\end{array}$ \\
\hline \multirow[t]{2}{*}{ Arkhangelsk Oblast } & GRP per capita $\left(\mathrm{y}_{1}\right)$ & $\begin{array}{l}\mathrm{y}_{1}=95.97+5.906 \mathrm{x}_{1} \\
\mathrm{y}_{1}=96.077+5.91 \mathrm{x}_{1}-0.03 \mathrm{x}_{2}\end{array}$ & $\begin{array}{l}0.62 \\
0.62\end{array}$ \\
\hline & Budget income $\left(\mathrm{y}_{2}\right)$ & $\mathrm{y}_{2}=15562+0.905 \mathrm{x}_{1}-0.401 \mathrm{x}_{2}$ & 0.62 \\
\hline \multirow[t]{2}{*}{ Vologda Oblast } & GRP per capita $\left(\mathrm{y}_{1}\right)$ & $\begin{array}{l}\mathrm{y}_{1}=-53.685+18.937 \mathrm{x}_{1} \\
\mathrm{y}_{1}=54.295+87.771 \mathrm{x}_{2} \\
\mathrm{y}_{1}=-49.738+16.812 \mathrm{x}_{1}+14.602 \mathrm{x}_{2}\end{array}$ & $\begin{array}{l}0.88 \\
0.63 \\
0.88 \\
\end{array}$ \\
\hline & Budget income $\left(\mathrm{y}_{2}\right)$ & $\begin{array}{l}\mathrm{y}_{2}=9.864+12.311 \mathrm{x}_{2} \\
\mathrm{y}_{2}=-3.153+2103 \mathrm{x}_{1}+3.156 \mathrm{x}_{2}\end{array}$ & $\begin{array}{l}0.70 \\
0.93\end{array}$ \\
\hline
\end{tabular}


The analysis of the obtained dependences given in the table allows to draw conclusions as to the extent to which the growth of investments into fixed capital and production volumes influences the amount of the gross regional product and the budget income of the considered regions with clusters:

1. Ryazan Oblast (textile cluster):

- with the investments into the fixed capital of the processing industry increased by 1 thousand rub., the GRP increases by 16565 rub., i.e., the coefficient of a multiplication in this case exceeds 16.5;

- with the production volume for «textile, sewing production, leather products and production of footwear» increased by 1 thousand rub., the GRP will increase by 5776 rub. at the same volume of investment into fixed capital. The increase in the volume of investments into fixed capital of the processing industry by 1 thousand rub. at the same volume of production implies GRP growth by 13010 rub., i.e. the multiplying influence of investments on the GRP exceeds a similar influence of the output increase of the cluster's enterprises by more than two times. At the same time, the production in the cluster is observed to experience a fast growth by almost 5 times with respect to the overall GRP;

- with the volume of investments into fixed capital of the processing industry increased by 1 thousand rub., the income of the budget will increase by 20337 rub., i.e., the coefficient of multiplication in this case exceeds 20.3. It is obvious that granting benefits for the investment activity of textile enterprises is economically justified;

- with the production volume for «textile, sewing production, leather products skin and production of footwear» increased by 1 thousand rub., the income of the budget will increase by 296 rub. at the same volume of investments into fixed capital. The increase in the volume of investments into fixed capital of the processing industry by 1 thousand rub. at the same volume of production leads to the income of the budget increasing by 2011 rub.

Thus, the performance of the enterprises from the «textile, sewing production, leather products and production of footwear» cluster in the Ryazan Oblast has a considerable positive impact on the growth of the GRP and the income of the budget, and investments into fixed capital of the processing industry pay off, having a substantial positive impact on the growth of these indicators. Therefore, the creation of a textile cluster in the Ryazan Oblast was expedient; this cluster has a substantial positive multiplying impact on the regional economy. In this regard, it is possible to conclude that the textile cluster of the Ryazan Oblast is effective.

2. Tula Oblast (power cluster):

- with the production volume for «production and distribution of the electric power, gas and water» increased by 1 thousand rub., the GRP will increase by more than by 11 times, i.e., by 11858 rub.;

- with the investments into fixed capital of production, transfer and distribution of the electric power, gas and water increased by 1 thousand rub., the GRP will increase even more considerably by 13198 rub.;

- with the production volume for «production and distribution of the electric power, gas and water» increased by 1 thousand rub., the GRP will increase by 8267 rub at the same volume of investments into fixed capital. The increase in the volume of investment into the fixed capital of production, transfer and distribution of the electric power, gas and water by 1 thousand rub. at the same production volume leads to an increase of the GRP by 7116 rub;

- with the production volume for «production and distribution of the electric power, gas and water» increased by 1 thousand rub., the income of the budget will increase by 2206 rub;

- with the volume of investments into fixed capital for production, transfer and distribution of the electric power, gas and water increased by 1 thousand rub., the income of the budget will increase by 2376 rub;

- with the production volume for «production and distribution of the electric power, gas and water» increased by 1 thousand rub., the income of the budget will increase by 1602 rub at the same volume of investments into fixed capital. The increase in the volume of investments into the fixed capital for production, transfer and distribution of the electric power, gas and water by 1 thousand rub. at the same production volume leads to an increase of the income of the budget by 1197 rub. 
Based on the obtained results, we can draw conclusions for the power cluster of the Tula Oblast similar to the above-formulated ones for the textile cluster of the Ryazan Oblast. Quantitative estimates of the cluster's impact on the indicators of the regional economy in the Tula Oblast are slightly lower than in the Ryazan Oblast. Nevertheless, the economic performance (investments and output) of the cluster's enterprises also has a positive multiplying impact on the regional economy. Quantitative distinctions which we found can be caused by territorial, industrial, technological, institutional and other factors; detailed analysis of these factors is outside the scope of this article.

3. Arkhangelsk Oblast (timber industry cluster):

- with the production volume of the pulp-andpaper industry increased by 1 thousand rub., the GRP will increase by 5906 rub. This means that this type of production is closely tied with the GRP, and the coefficient of multiplication is almost equal to 6 units;

- with the production volume of the pulp-andpaper industry increased by 1 thousand rub., the GRP will increase by 5910 rub. at the same volume of investments into fixed capital; the increase in the volume of investments into the fixed capital of the processing industry by 1 thousand rub. at the same volume of production will cause a reduction of the GRP by 0.03 thousand rubles. Though this reduction is insignificant (it is possible to explain it by statistical error), but it is still present and thus demands further study;

- with the production volume of the pulpand-paper industry increased by 1 thousand rub., the income of the budget will increase by 905 rub. (a very significant increase which can indicate, firstly, the considerable multiplying influence of the pulp-and-paper industry on the economic activity in the Arkhangelsk Oblast, and, secondly, the raised tax burden of this branch) at the same volume of investment into fixed capital. With the volume of investment into fixed capital of the processing industry increased by 1 thousand rub. at the same volume of production, the income of the budget will be reduced by 401 rub. It is worth focusing on this last result: the mechanism of its formation is not quite clear. It then follows that the growth of investment activity in the Arkhangelsk Oblast is undesirable from the positions of budget formation. It reduces the income of the budget. This result cannot be explained by calculation errors or inaccuracies of the basic data (as we did in the previous subparagraph): the ratio of investment growth to the decrease in the budgetary income equals $5: 2$ and is rather significant.

The obtained results testify that the performance of the timber industry cluster in the Arkhangelsk Oblast has a positive impact on the economy of the region, increasing the GRP and the income of the budget. However, investments into the fixed capital of the processing industry in this case are not effective as the increase in their volume leads to a reduction of both the GRP and the income of the budget. Thus, the Pomorinnovales innovative territorial timber industry cluster can be considered effective from positions of development of the regional economy, but a revision of the investment policy of the region, and improvement of its mechanisms are necessary.

4. Vologda Oblast (dairy cluster):

- with the production volume of the agricultural industry increased by 1 thousand rub., the GRP will increase by 18937 rub. In this case we recorded the greatest numerical value of the multiplier, 18.9. This means that the development of the agricultural industry (if we judge by the considered selection of clusters) has the greatest multiplying impact on the regional economy. We connect it with the circumstance that the creation of agroclusters means not only production, but also processing of the agricultural products in the territory of the region where the cluster is located, which in turn generates additional types of economic activity, additional workplaces and added value;

- with the volume of investments into the fixed capital of agriculture, hunting and forestry increased by 1 thousand rub., the GRP will increase by $87771 \mathrm{rub}$. This means that here we observe an even larger multiplying impact on the development of the regional economy than the one we considered in the previous subparagraph. This confirms the conclusion about the priority of state support of production and processing of agricultural products. The crux of the matter here is not in solving social (support of the rural 
areas) or political (ensuring food security) tasks, but in purely economic reasons. This support generates a very high economic effect;

- with growth of volume of release of agricultural production increased by 1 thousand rub., GRP will increase for 16812 rub at the same volume of investment into fixed capital. The increase in the volume of investment into fixed capital of agriculture, hunting and forestry increased by 1 thousand rub., at the same volume of production, will cause increase of GRP on 14602 thousand rubles. Thus, and at joint increase in two influencing factors considered by us, the resultant variable shows very high sensitivity;

- with the volume of investments into the fixed capital of agriculture, hunting and forestry increased by 1 thousand rub., the income of the budget will increase by 12311 rub. This circumstance seems very important to us. It is an additional argument for state support (including within the existing institutional regulations and financial ) of agrocluster development;

- with the volume of agricultural production increased by 1 thousand rub., the income of the budget will increase by 2013 rub at the same volume of investments into fixed capital. The volume of investments into the fixed capital of agriculture, hunting and forestry increased by 1 thousand rub. at the same volume of production will cause an increase of the income of the budget by 3156 thousand rubles.

Thus, calculations showed that the performance of the agricultural enterprises in the Vologda Oblast and investments into the working capital of agriculture, hunting and forestry have a very significant positive impact on the growth of the GRP and the income of the budget. It follows from this that the dairy cluster created in the region functions in an effective specialization branch, and the full support of its development is necessary and economically expedient.

Conclusions. Summing up the results, we will note that the hypothesis we advanced about the positive influence that clustering has on the regional economy was confirmed quantitatively. This influence was proved by means of quantitative methods using enough representative datasets (covering 11 years). Our study undoubtedly had a selective character: it does not seem possible to carry out calculations for all cluster initiatives existing in Russia and to discuss their results within a single article. At the same time, following the results of the analysis we carried out, it is possible to draw a conclusion on the efficiency of creating clusters in Russian regions. Cluster activity is capable of having a positive impact on the growth of GRP and the budgetary income in the region. Along with it, we noticed differences in the multiplying influence of clusters on regional development, and its dependence on territorial and branch specifics. Apparently, this question requires further in-depth study.

The study was conducted within NIR N 26.2671.2014/K and N 26.1303.2014/K of design part of the state task of the Ministry of Education and Science of the Russian Federation in the sphere of scientific activity.

\section{REFERENCES}

1. Arkin P.A., Golubev A.G. Structurization of innovative process in a cluster: information and logistic method. News of the St. Petersburg state economic university, 2014, no. 1, pp. 58-62. (rus)

2. Babkin A.V., Novikov A.O. Cluster as a subject of economy: essence, current state, development. St. Petersburg State Polytechnical University Journal. Economics, 2016, no. 1(235), pp. 9-29. DOI: 10.5862/JE.235.1 (rus)

3. Badgers D.P., Kudryashov V.S. Formation of an industrial cluster: theoretical and methodical aspects: monograph. St. Petersburg, 2014. (rus)

4. Borodkina E.V., Risin I.E. Public administration by processes of a clustering of social and economic space of the region: monograph.
Voronezh, Publishing house of VGPU, 2011. 159 p. (rus)

5. Vertakova Yu.V., Plotnikov V.A. Tipologization's Carpenters of approaches to formation and development of propulsive clusters in region economy. Economy and management, 2016, no. 3(125), pp. 1018. (rus)

6. Vertakova Yu.V., Polozhentseva Yu.S., Hlynin M.Yu. Formation and development of industrial clusters. Technical and technological problems of service, 2014, no. 1(27), pp. 92-99. (rus)

7. Gordey K.G. Konfigurirovaniye of systems of deliveries in a format of a logistic cluster. The Theory and practice of service: economy, social sphere, technologies, 2015, no. 2(24), pp. 69-72. (rus) 
8. Gorelova Ya.S. Comparison of clusters and other forms of the organizations. News of the St. Petersburg state economic university, 2015, no. 6, pp. 103-105. (rus)

9. Cluster structure of an industrial economy: the monograph. Under the editorship of A.V. Babkin. St. Petersburg, St. Petersburg state polytechnical university, 2014. 300 p. (rus)

10. Carpenters of VA., Sergeyev P.V., Timofeeva S.V. Innovative and technological support of management of development of regional pharmaceutical clusters. News of Southwest state university. Series: Economy. Sociology. Management, 2011, no. 2, pp. 92-97. (rus)

11. Svetovtseva M.G. Management of formation of an economic kernel of the region: yew. ... edging. экон. sciences. Voronezh, 2004. 270 p. (rus)

12. Soloveychik K.A. Conceptual bases of creation of innovative industrial clusters in Russia: monograph. St. Petersburg, Publisher of the St. Petersburg state. un-t of economy and finance, 2010. (rus)

13. Clusters and Regional Specialisation. On Geography, Technology and Networks. Ed. by M. Steiner. London, Pion, 1998.

14. Delgado M., Porter M., Stern S. Clusters, Convergence, and Economic Performance. Institute for Strategy and Competitiveness. March 11, 2011.

15. Porter M.E. Clusters and the new economics of competition. Harvard Business Review, 1998, no. 76(6), pp. 77-90.

\section{СПИСОК ЛИТЕРАТУРЫ}

1. Аркин П.А., Голубев А.Г. Структуризация инновационного процесса в кластере: информационно-логистический метод // Известия СанктПетербургского государственного экономического университета. 2014. № 1. С. 58-62.

2. Бабкин А.В., Новиков А.О. Кластер как субъект экономики: сущность, современное состояние, развитие // Научно-технические ведомости Санкт-Петербургского государственного политехнического университета. Экономические науки. 2016. № 1(235). С. 9-29. DOI: 10.5862/JE.235.1

3. Барсуков Д.П., Кудряшов В.С. Формирование промышленного кластера: теоретические и методические аспекты: моногр. СПб., 2014.

4. Бородкина Е.В., Рисин И.Е. Государственное управление процессами кластеризации социально-экономического пространства региона: моногр. Воронеж: Изд-во ВГПУ, 2011. 159 с.

5. Вертакова Ю.В., Плотников В.А. Типологизация подходов к формированию и развитию пропульсивных кластеров в экономике региона // Экономика и управление. 2016. № 3(125). С. 10-18.

6. Вертакова Ю.В., Положенцева Ю.С., Хлынин М.Ю. Формирование и развитие промышленных кластеров // Технико-технологические проблемы сервиса. 2014. № 1(27). С. 92-99.

7. Гордей К.Г. Конфигурирование систем поставок в формате логистического кластера // Теория и практика сервиса: экономика, социальная сфера, технологии. 2015. № 2(24). С. 69-72.

8. Горелова Я.С. Сравнение кластеров и других форм организаций // Известия Санкт-Петербургского государственного экономического университета. 2015. № 6. С. 103-105.

9. Кластерная структура экономики промышленности: моногр. / под ред. А.В. Бабкина. СПб.: Изд-во Политехн. ун-та, 2014. 300 с.

10. Плотников В.А., Сергеев П.В., Тимофеева С.В. Инновационно-технологическая поддержка управления развитием региональных фармацевтических кластеров // Известия Юго-Западного государственного университета. Серия: Экономика. Социология. Менеджмент. 2011. № 2. С. 92-97.

11. Световцева М.Г. Управление формированием экономического ядра региона: дис. ... канд. экон. наук. Воронеж, 2004. 270 с.

12. Соловейчик К.А. Концептуальные основы создания инновационных промышленных кластеров в России: моногр. СПб.: Изд-во СПбГУЭФ, 2010.

13. Clusters and Regional Specialisation. On Geography, Technology and Networks / ed. by M. Steiner. London: Pion, 1998.

14. Delgado M., Porter M., Stern S. Clusters, Convergence, and Economic Performance. - Institute for Strategy and Competitiveness. March 11, 2011.

15. Porter M.E. Clusters and the new economics of competition // Harvard Business Review, 1998, no. 76(6). pp. 77-90.

BABKIN Alexander V. - professor of the Higher school of industrial management and economy of the St. Petersburg polytechnical university of Peter the Great, the Doctor of Economics, professor.

195251, Politekhnicheskaya str. 29. St. Petersburg. Russia. Phone: 8(812)591-66-58. E-mail babkin@spbstu.ru, al-vas@mail.ru

БАБКИН Александр Васильевич - профессор Высшей школы промышленного менеджмента и экономики Санкт-Петербургского политехнического университета Петра Великого, доктор экономических наук, профессор;

195251, ул. Политехническая, д. 29, Санкт-Петербург, Россия. Тел.: 8(812)591-66-58.E-mail: babkin@spbstu.ru, al-vas@mail.ru. 
VERTAKOVA Yuliya V. - department of regional economics and management, faculty of Economics and Management, Southwest State University, Head of the department of regional economics and management.

305040. 50 let Oktyabrya str. 94. Kursk. Russia. E-mail: vertakova7@yandex.ru

ВЕРТАКОВА Юлия Владимировна - заведующий кафедрой «Региональная экономика и менеджмент» Юго-Западного государственного университета, доктор экономических наук.

305040, ул. 50 лет Октября, д. 94, г. Курск, Россия. Тел. +7(910)316-66-71. E-mail: vertakova7@yandex.ru

PLOTNIKOV Vladimir A. - Saint-Petersburg State University of Economics.

191023. Sadovaya str. 21. St. Petersburg. Russia. E-mail: Plotnikov_2000@mail.ru

ПЛОТНИКОВ Владимир Александрович - профессор Санкт-Петербургского государственного экономического университета, доктор экономических наук, профессор.

191023, ул. Садовая, д. 21, Санкт-Петербург, Россия. Тел.: 8(911)949-13-21. E-mail: Plotnikov_2000@mail.ru

(C) Peter the Great Saint-Petersburg Polytechnic University, 2016 